\title{
Impaired Monocyte Migration and Reduced Type 1 (Th1) Cytokine Responses in C-C Chemokine Receptor 2 Knockout Mice
}

\author{
Landin Boring, ${ }^{*}$ Jennifa Gosling, ${ }^{\star}$ Stephen W. Chensue, ${ }^{\S} \|$ Steven L. Kunkel, $\|$ Robert V. Farese, Jr., ${ }^{\star \ddagger}$ Hal E. Broxmeyer, \\ and Israel F. Charo* \\ * Gladstone Institute of Cardiovascular Disease, ${ }^{\ddagger}$ Cardiovascular Research Institute, and the Department of Medicine, University of \\ California, San Francisco, California 94141-9100; ${ }^{\S}$ Department of Pathology, Veterans Affairs Medical Center and $\|^{\|}$Department of \\ Pathology, University of Michigan Hospitals, University of Michigan, Ann Arbor, Michigan 48109; and $\mathbb{I}$ Department of Microbiology, \\ Immunology and Walther Oncology Center, Indiana University Medical Center, and Walther Cancer Institute, Indianapolis, Indiana 46202
}

\begin{abstract}
Monocyte chemoattractant protein-1 (MCP-1) is a potent agonist for mononuclear leukocytes and has been implicated in the pathogenesis of atherosclerosis and granulomatous lung disease. To determine the role of MCP-1 and related family members in vivo, we used homologous recombination in embryonic stem cells to generate mice with a targeted disruption of C-C chemokine receptor 2 (CCR2), the receptor for MCP-1. CCR2 ${ }^{-l-}$ mice were born at the expected Mendelian ratios and developed normally. In response to thioglycollate, the recruitment of peritoneal macrophages decreased selectively. In in vitro chemotaxis assays, CCR2 $2^{-1-}$ leukocytes failed to migrate in response to MCP-1. Granulomatous lung disease was induced in presensitized mice by embolization with beads coupled to purified protein derivative (PPD) of Mycobacterium bovis. As compared with wild-type littermates, CCR2 $2^{-1-}$ mice had a decrease in granuloma size accompanied by a dramatic decrease in the level of interferon $\gamma$ in the draining lymph nodes. Production of interferon $\gamma$ was also decreased in PPD-sensitized splenocytes from $\mathrm{CCR} 2^{-1-}$ mice and in naive splenocytes activated by concanavalin $\mathrm{A}$. We conclude that $\mathrm{CCR} 2^{-1-}$ mice have significant defects in both delayedtype hypersensitivity responses and production of Th1-type cytokines. These data suggest an important and unexpected role for CCR2 activation in modulating the immune response, as well as in recruiting monocytes/macrophages to sites of inflammation. (J. Clin. Invest. 1997. 100:2552-2561.) Key words: MCP-1 - inflammation - chemokines • chemokine receptor $\bullet$ homologous recombination
\end{abstract}

\section{Introduction}

Directed migration of leukocytes in response to inflammatory stimuli is crucial for the cellular and adaptive immune response. The chemokines (chemotactic cytokines) are a growing superfamily of $8-10-\mathrm{kD}$ peptides that selectively attract and activate leukocyte populations (see references 1-5).

Address correspondence to Israel F. Charo, Gladstone Institute of Cardiovascular Disease, P.O. Box 419100, San Francisco, CA 941419100. Phone: 415-826-7500; FAX: 415-285-5632; E-mail: izzy_charo. gicd@quickmail.ucsf.edu

Received for publication 28 July 1997.

The Journal of Clinical Investigation

Volume 100, Number 10, November 1997, 2552-2561

http://www.jci.org
Monocyte chemoattractant protein $(\mathrm{MCP})^{1}-1$ is a member of the $\mathrm{C}-\mathrm{C}$ branch of the chemokine family, is a potent monocyte and lymphocyte chemoattractant $(6,7)$, and induces histamine release from basophils (8). In vivo studies suggest that MCP-1 recruits monocytes to sites of inflammation in a variety of pathological conditions, including atherosclerosis (9-11), rheumatoid arthritis (12), and pulmonary fibrosis and granulomatous lung disease (13). Recent data indicate that MCP-1 and other C-C chemokines augment cytotoxic lymphocyte and natural killer cell activity in vitro $(14,15)$, suggesting a novel role for chemokines as costimulators of $\mathrm{T}$ cell activation. In addition, MCP-1 and other chemokines have been shown to inhibit the proliferation of myeloid progenitor cells both in vitro and in vivo (16).

The effects of chemokines are mediated by a family of closely related $\mathrm{G}$ protein-coupled receptors. MCP-1 initiates signal transduction through binding to $\mathrm{C}-\mathrm{C}$ chemokine receptor 2 (CCR2) (17). Like most chemokine receptors, CCR2 is activated by multiple agonists, including $\operatorname{MCP}-3$ (18, 19), MCP-4 (20, 21), and MCP-5 (22). In addition, in vitro studies using cloned receptors indicate that CCR2 agonists also bind and activate other receptors; for example, MCP-3 activates CCR1 (19), and MCP-3 and MCP-4 activate CCR3 (20, 21). However, only chemokines of the MCP family (MCP-1 through MCP-5) appear to activate CCR2. The multiplicity of receptor usage suggests that chemokines may have redundant functions in vivo.

Since much of the literature addressing the role of MCP-1 in disease states is correlative and because of the multiplicity of agonists for the MCP-1 receptor, we used homologous recombination in embryonic stem (ES) cells to delete the gene encoding CCR2 in mice. Mice homozygous for a deletion of the CCR2 gene $\left(\mathrm{CCR} 2^{-/-}\right)$were viable, fertile, and indistinguishable from wild-type littermates while maintained in a pathogen-free environment. To test the hypothesis that CCR2 is required for recruitment of leukocytes during inflammatory reactions, we challenged $\mathrm{CCR} 2^{-1-}$ mice with nonspecific inflammatory stimuli and with a mycobacterial antigen that induces a type 1 cytokine response. Our results indicate that CCR2 is the primary receptor for MCP-1 in the mouse and suggest important roles in monocyte recruitment and regulation of the production of inflammatory cytokines.

1. Abbreviations used in this paper: APC, antigen-presenting cell; BFU-E; burst-forming units-erythrocyte; CCR2, C-C chemokine receptor 2; CFU-GM, colony-forming units-granulocyte/macrophage; ConA, concanavalin A; ES, embryonic stem; GEMM, multipotential progenitor cells; MCP, monocyte chemoattractant protein; PPD, purified protein derivative; Th1, type 1 cytokine; Th2, type 2 cytokine. 


\section{Methods}

Reagents. Recombinant chemokines were obtained from R\&D Systems (Minneapolis, MN) except for recombinant murine MCP-5, which was a generous gift of Dr. Andrew Luster (Harvard Medical School, Boston, MA) (22).

Generation of CCR 2 mutant mice. Genomic DNA containing the murine CCR2 gene was isolated from a 129/Sv strain library constructed in $\lambda$ FIX (Stratagene, Inc., San Diego, CA) and was screened with a probe specific for the $3^{\prime}$ untranslated region of the murine CCR 2 cDNA (23). A phage containing a hybridizing insert of $\sim 12.0 \mathrm{~kb}$ was plaque purified and digested with NotI, and the insert was subcloned into the NotI site of pBluescriptSK $(+)$ (pBS; Stratagene, Inc.). Southern mapping revealed that the insert contained only $1.0 \mathrm{~kb}$ of $5^{\prime}$ noncoding sequence. Therefore, we screened a bacteriophage P1 clone (Genome Systems, St. Louis, MO) with an insert of $\sim 85 \mathrm{~kb}$ (data not shown) that contains both the CCR2 and CCR5 genes (23) using a probe located $5^{\prime}$ to the coding region. Hybridizing fragments were subcloned into $\mathrm{pBS}$, and a BamHI fragment was obtained that extended $\sim 8.0 \mathrm{~kb}$ upstream from the coding region of CCR2 (see Fig. 1).

To construct the short arm of the targeting vector, primers containing XhoI restriction sites were used to amplify a $0.7-\mathrm{kb}$ fragment extending upstream from the amino-terminus of the receptor using subcloned genomic DNA as a template (SA1, 5'-GCCTCGAGTGCCGTGGATGAACTGAGG-3', located 39 bp downstream of the first ATG codon; SA2 5'-GCCTCGAGGGAAATCAACTTGGGTTCTATGC-3' located $\sim 0.7 \mathrm{~kb}$ upstream, see Fig. 1). The PCR product was cloned into the XhoI site of pPolIIshort-neobpA-HSVTK (a generous gift of S. Ishibashi, University of Tokyo, Japan [24]), creating pSAneoTK. To provide the $3^{\prime}$ region of homology, an 8.0-kb BamHI fragment located downstream of the cDNA was cloned into the BamHI site of pSAneoTK (Fig. 1). Transcription of the neo gene is opposite to that of CCR2. The targeting vector was linearized $3^{\prime}$ to the long arm of homology with a unique NotI site in the polylinker.

The CCR2 targeting vector was electroporated into RF8 ES cells cultured on LIF-producing STO feeder cells, as previously described (25). Clones resistant to both G418 $(150 \mu \mathrm{g} / \mathrm{ml})$ and FIAU $(0.25 \mathrm{mM})$ were screened by PCR with primers located in the neo cassette and upstream of the short arm of homology (GHpA 5'-GGAAGACAATAGCAGGCATGC-3', SA3 5'-GCCTCGAGGCAGCCACGTAGGTGTC- $3^{\prime}$ ) to yield a product of $\sim 1.0 \mathrm{~kb}$ in correctly targeted clones. Homologous recombination was further verified by Southern analysis of HindIII-digested genomic DNA hybridized with a probe located 5' of the targeting vector (Fig. 1).

Analysis of $m R N A$ expression. Total RNA was prepared from spleens and peritoneal exudate cells and screened for CCR2 and CCR5 mRNA by reverse transcriptase PCR with primers that we previously demonstrated to be specific for each receptor (CCR2 forward 5'-GGTCATGATCCCTATGTGG-3', reverse 5'-CTGGGCACCTGATTTAAAGG-3'; CCR5 forward 5'-CGGTGTTCAATTTTCC-3', reverse 5'-CCATTCCTACTCCCAAGCTGC-3' [23]). After synthesis of cDNA with an oligo-dT primer, PCR was performed with a GeneAmp Kit (Perkin-Elmer Corp., Branchburg, NJ) according to the manufacturer's protocol. The predicted products are 242 and 148 bp for CCR2 and CCR5, respectively.

Chemotaxis assays. Peritoneal exudate cells were elicited by intraperitoneal injection of $3.0 \mathrm{ml}$ of $3 \%$ Brewer thioglycollate medium (Difco, Detroit, MI). 3 d later, cells were harvested by peritoneal lavage with ice-cold PBS, washed three times with cold PBS, and resuspended at $2.0 \times 10^{6}$ cells $/ \mathrm{ml}$ in RPMI (Gibco/Life Sciences, Grand Island, NY) containing $1.0 \mathrm{mg} / \mathrm{ml}$ bovine serum albumin (fraction $\mathrm{V}$, Sigma Chemical Co., St. Louis, MO). Chemotaxis assays were performed in 48-well Boyden chambers (Neuroprobe, Cabin John, MD) using $5-\mu \mathrm{m}$ pore PVPF membranes (Poretics, Livermore, CA) to separate the agonist (lower chamber) from the cells $\left(10^{5} /\right.$ well). Chambers were incubated at $37^{\circ} \mathrm{C}$ in an atmosphere of $5 \% \mathrm{CO}_{2}$ for $90 \mathrm{~min}$, and cells that migrated through and adhered to the bottom of the filter were stained with Diff-Quick (Dade Diagnostics, Aguada, Puerto Rico).
Five high-power fields were counted per well, and each data point was determined in triplicate. Each agonist was tested in at least three independent experiments. Aliquots (10,000 cells) used for chemotaxis assays were dispersed by cytospin $(500 \mathrm{rpm}, 5 \mathrm{~min}$ ) (Shandon, Pittsburgh, PA) and stained with Diff-Quick. Cell types were identified by morphology and immunocytochemistry using F4/80 (macrophages) (BioSource International, Camarillo, CA), Gr1 (neutrophils), CD11b (macrophages and neutrophils), and CD3 (T lymphocytes) (PharMingen, San Diego, CA). At least 200 cells were counted for each animal.

Lung granuloma induction. Pulmonary granulomas with predominantly Th1 cytokine profiles were generated as described (13). Briefly, mice were sensitized by subcutaneous injection near the nape of the neck with $20 \mu \mathrm{g}$ of Mycobacteria bovis purified protein derivative (PPD) (National Veterinary Services Laboratory, Ames, IA) in $0.25 \mathrm{ml}$ of complete Freund's adjuvant. Sensitized mice were challenged 14-16 d later by an intravenous infusion of 6,000 Sepharose 4B beads (in $0.5 \mathrm{ml}$ PBS) covalently coupled to PPD. Beads embolized to the lungs and elicited granulomas that were examined 2, 4, and $8 \mathrm{~d}$ later, after killing of the animals. The lungs were perfused with cold RPMI and removed, excluding the trachea and major bronchi. The right lung was snap frozen in liquid nitrogen for mRNA isolation. The left lung was homogenized in cold RPMI in a Waring blender with a narrow-bottom stainless-steel cup. Intact granulomas were collected over a sterile stainless-steel mesh (No. 100), and the cells isolated by digestion with collagenase (1,000 U/ml type IV, Sigma Chemical Co.) dissolved in RPMI supplemented with $10 \%$ FBS for $30 \mathrm{~min}$ in a $37^{\circ} \mathrm{C}$ shaking water bath, followed by passage through a stainlesssteel mesh (No. 100). Differential counts of granuloma cell suspensions were obtained from duplicate cytospin preparations stained with Wright's stain. To measure granuloma area, lungs were inflated with formalin, embedded in paraffin, sectioned, and stained with hematoxylin and eosin. Granulomas were measured by a "blinded" observer with a morphometer and software (The Morphometer; Woods Hole Educational Associates, Woods Hole, MA). A minimum of 20 lesions were measured per lung.

Lymph node cytokine production. Mediastinal lymph nodes were collected at the time of lung harvest and dispersed into single-cell suspensions. After washing, the cells $\left(5 \times 10^{6} / \mathrm{ml}\right)$ were cultured in RPMI supplemented with $10 \%$ FBS, $10 \mathrm{mM}$ glutamine, $100 \mu \mathrm{g} / \mathrm{ml}$ streptomycin, and $100 \mathrm{U} / \mathrm{ml}$ penicillin in the presence or absence of 5 $\mu \mathrm{g} / \mathrm{ml} \mathrm{PPD}$ at $37^{\circ} \mathrm{C}$ for $24 \mathrm{~h}$ in a $5 \% \mathrm{CO}_{2}$ humidified atmosphere. Supernatants were collected by centrifugation and stored at $-45^{\circ} \mathrm{C}$, and cytokine measurements were made by ELISA as described (13).

$T$ lymphocyte, spleenocyte, and antigen-presenting cell function. Antigen-presenting cell (APC) monolayers were isolated from the dispersed spleens of naive wild-type and mutant mice by adherence to $35-\mathrm{mm}$ plastic culture dishes for $2 \mathrm{~h}$ at $37^{\circ} \mathrm{C}$. T cells were prepared from individual spleens of PPD-sensitized mice. Red blood cells were removed by hypotonic lysis, and $\mathrm{T}$ cells were isolated by the panning method of Mage et al. (26). T cells were further depleted of APC by passage through sterile G10 Sephadex columns (27). The T cells were overlaid onto wild-type or mutant APC monolayers at $3 \times 10^{6} / \mathrm{ml}$ in RPMI/FBS and cultured for $24 \mathrm{~h}$ in the presence of $5 \mu \mathrm{g} / \mathrm{ml}$ PPD. Control cultures consisted of APC monolayers only and T cells without APC. In some experiments, spleens from naive mice were collected, dispersed into single-cell suspensions, and maintained at $1 \times$ $10^{7} / \mathrm{ml}$ in RPMI/FBS for $24 \mathrm{~h}$ in the presence or absence of $5 \mu \mathrm{g} / \mathrm{ml}$ concanavalin A (ConA). Supernatants were collected as above for cytokine assays.

Colony forming assays and peripheral blood counts. Granulocytemacrophage (CFU-GM), erythroid (BFU-E), and multipotential (CFUGEMM) progenitors were scored based on colony formation in $1 \%$ methylcellulose culture medium supplemented with $30 \% \mathrm{FBS}, 1 \mathrm{U} / \mathrm{ml}$ recombinant human erythropoietin, $5 \% \mathrm{vol} / \mathrm{vol}$ pokeweed mitogen mouse spleen conditioned medium, $50 \mathrm{ng} / \mathrm{ml}$ murine steel factor, and $0.1 \mathrm{mM}$ hemin, as described $(16,28)$. Unseparated marrow, unseparated spleen, and low-density blood cells were plated, respectively, at $5 \times 10^{4}, 5 \times 10^{5}$, and $1 \times 10^{5}$ cells $/ \mathrm{ml}$, and colonies were scored after 
Wild-type CCR2 allele
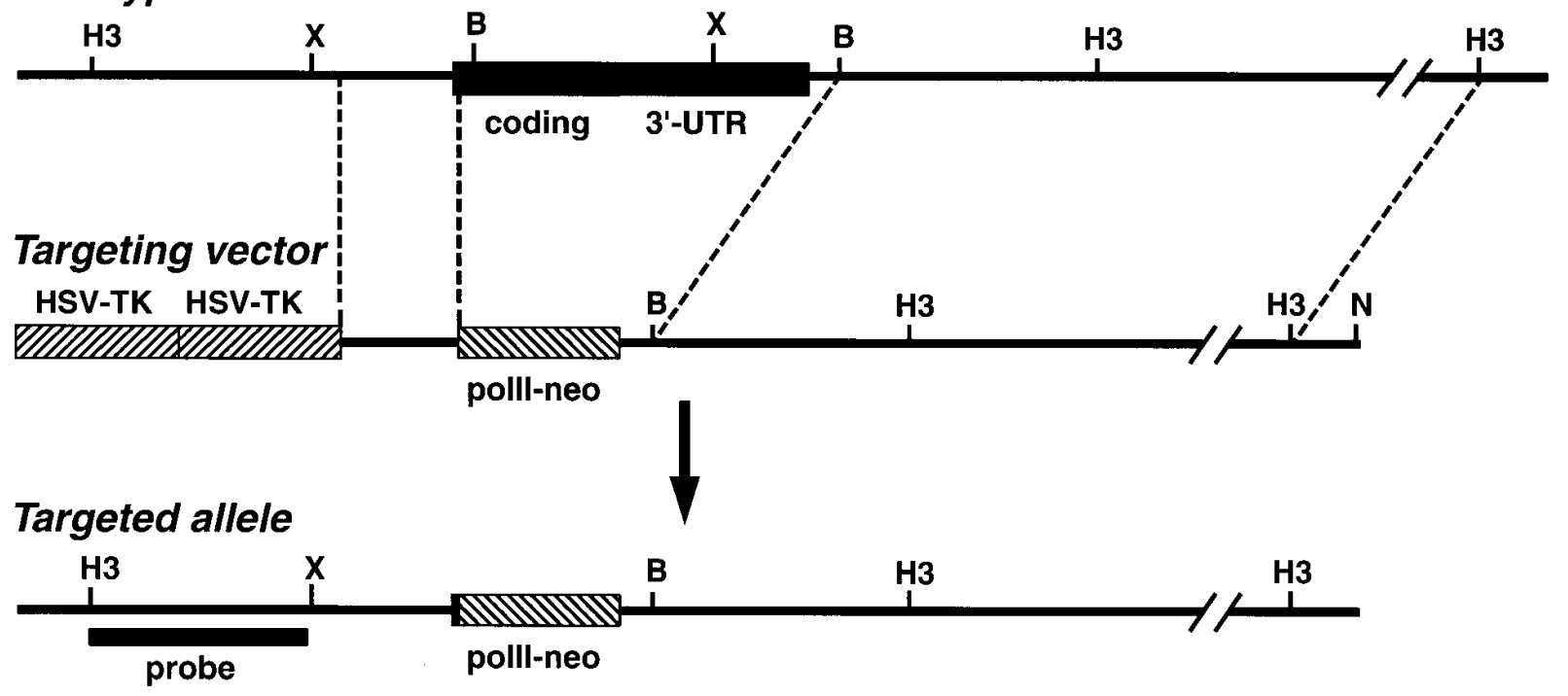

B $\quad \frac{1}{1} \frac{1}{+} \frac{1}{+} \frac{1}{+} \frac{1}{+} \frac{1}{1}+\frac{1}{+}+\frac{1}{+} \frac{1}{1}$

$23.1 \mathrm{~kb}-$
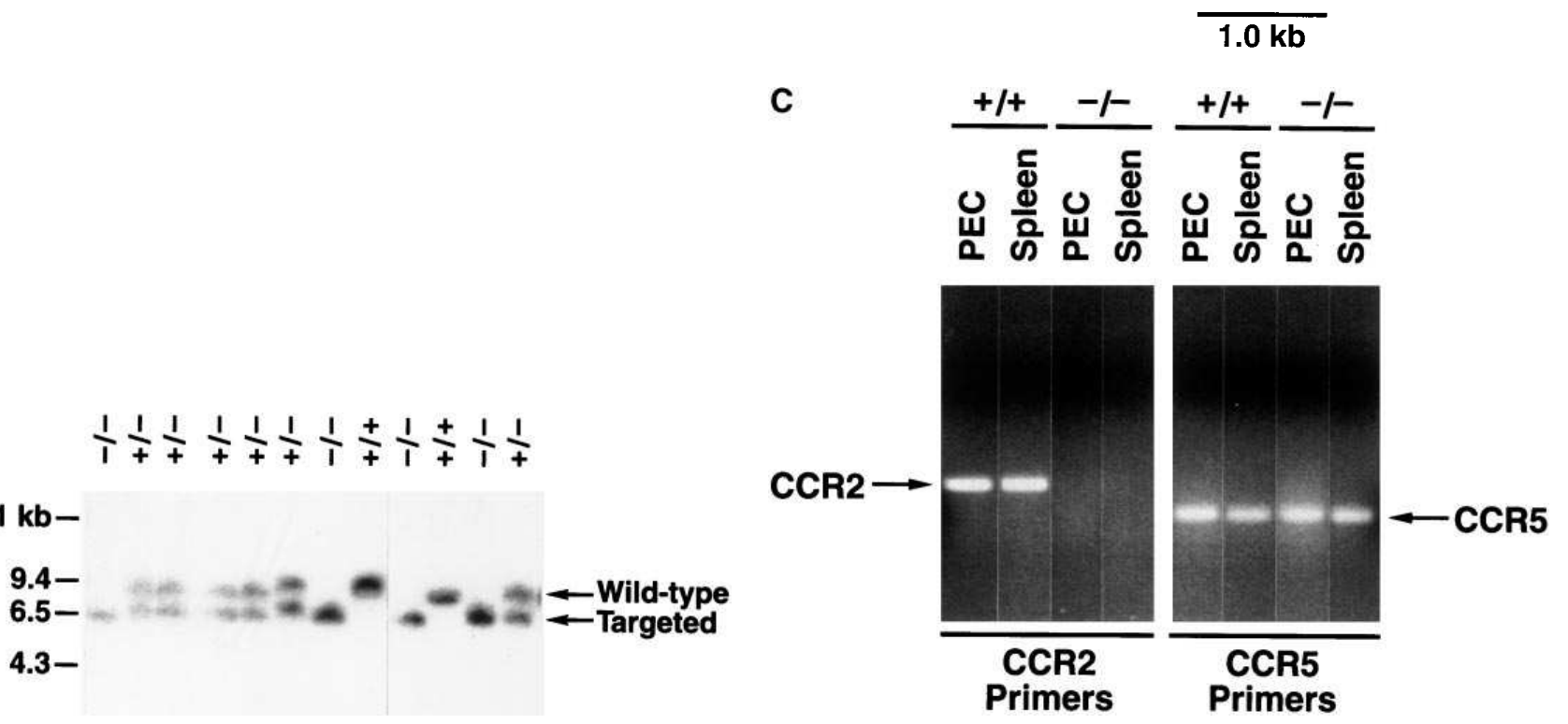

Figure 1. Targeted deletion of the CCR2 gene. (A) Targeting strategy. Shown on the top line is a partial restriction map of the wild-type CCR2 gene locus. The targeting vector is shown in the center, and the predicted structure of the targeted allele after homologous recombination is shown below. The exon containing the coding and 3' untranslated regions is indicated as a filled box; the polII-neo gene and the tandem HSV-TK genes are indicated by hatching. The probe used for screening of genomic DNA is shown by the thick black bar (probe). Restriction enzyme digestion with HindIII (H3) produces a wild-type fragment of $7.8 \mathrm{~kb}$ and a targeted fragment of $6.1 \mathrm{~kb}$. Restriction endonuclease sites are BamHI $(B)$, NotI $(N)$, and XbaI $(X)$. $(B)$ Generation of CCR2 mutant mice. Genomic DNA from $\mathrm{F} 2$ offspring of heterozygous $(+/-)$ parents was digested with $\mathrm{H} 3$ and hybridized with the probe indicated in $(A)$. The wild-type and targeted fragments are indicated, and the genotype of each mouse is shown above the lane. $+/+$, wild-type; $+/-$, heterozygous; $-/-$, homozygous mutant for CCR2. (C) Absence of CCR2 expression in CCR2 $2^{-l-}$ mice. mRNA was isolated from individual spleens of untreated mice and peritoneal exudate cells (PEC) $3 \mathrm{~d}$ after intraperitoneal injection of thioglycollate (PEC were pooled from three wild-type and six CCR2 $2^{-1-}$ mice) and subjected to reverse transcriptase PCR analysis with primers specific for CCR2 (lanes 1-4) and CCR5 (lanes 5-8). The products for CCR2 (242 bp) and CCR5 (148 bp) are indicated.

a 7-d incubation. Absolute numbers of progenitors were calculated based on the numbers of colonies per number of cells plated and on the nuclear cellularity of the organ. Peripheral blood cell counts were performed by Consolidated Veterinary Services, Inc. (West Sacramento, CA).

Flow cytometry analysis. Spleens of naive mice were dispersed into single-cell suspensions, and the red blood cells were lysed according to standard protocols (29). Cells $\left(10^{6}\right)$ were initially incubated with rat antibodies against mouse Fc $\gamma$ II and Fc $\gamma$ III receptors to block nonspecific binding to $\mathrm{Fc}$ receptors according to the manufacturer's protocol (PharMingen), then stained on ice for 30-60 min with 0.5$1.0 \mu \mathrm{g}$ of antibody in $\mathrm{HBSS} / 1.0 \% \mathrm{BSA} / 0.1 \% \mathrm{NaN}_{3}$. The following monoclonal antibodies were used: hamster anti-mouse CD3/FITC; rat anti-mouse CD4/PE, CD8/FITC, B220/PE, IgM/FITC, and $\mathrm{CD} 11 \mathrm{~b} /$ biotin (PharMingen). Biotinylated primary antibodies were detected by secondary incubation with streptavidin/PE (PharMingen) 
for $30 \mathrm{~min}$ on ice. Cells were also stained with appropriate control $\mathrm{IgG}$ antibodies (hamster $\mathrm{IgG} / \mathrm{FITC}$ and rat $\mathrm{IgG} / \mathrm{PE}$ or $\mathrm{IgG} / \mathrm{biotin}$, also from PharMingen) to determine nonspecific binding. Cell surface expression was analyzed with a FACScan ${ }^{\circledR}$ flow cytometer and CellQuest software (Becton-Dickinson Co., Mountain View, CA).

Cytokine measurements. Interleukins 2, 4, 5, 10, and 12 (p35/40 subunits) were measured by ELISA using commercially available reagents (PharMingen); sensitivities were to at least $50 \mathrm{pg} / \mathrm{ml}$. Commercially available recombinant murine cytokines served as standards in all assays (Genzyme Corp., Boston, MA, and Peprotech, Rocky Hills, NJ). IFN- $\gamma$ was measured by ELISA as described (13) using a capture antibody derived from the XMG-6 clone; sensitivity was to $50 \mathrm{pg} / \mathrm{ml}$. Recombinant murine IL-12 was kindly provided by Genetics Institute (Cambridge, MA).

Statistical analysis. The data for leukocyte recruitment into the peritoneum were analyzed using the Mann-Whitney test. All other data were analyzed by the Student's $t$ test (two-tailed). $P$ values $<$ 0.05 were considered significant.

\section{Results}

Generation of mice mutant for CCR2. To selectively delete CCR2, we constructed a targeting vector (Fig. $1 A$ ). This vector was designed to replace all but the first 39 nucleotides of the coding region of the receptor with a neo cassette via homologous recombination with the CCR2 gene. After electroporation into ES cells, 976 neomycin-resistant colonies were picked, one of which contained the correctly targeted allele. This clone was injected into C57BL/6 blastocysts, resulting in a chimeric male that transmitted the mutation to his offspring. Matings between heterozygous offspring resulted in mice homozygous for the CCR2 mutation $\left(\mathrm{CCR}^{-1-}\right)$ (Fig. 1 $B)$. CCR2 ${ }^{-l-}$ mice were born at the expected Mendelian ratios, showed no overt developmental or morphological abnormalities, and were fertile. The mice used in this study were hybrids between C57BL/6 and 129/Sv strains.

To confirm that the mutation selectively disrupted CCR2 transcription, we isolated RNA from spleens and thioglycollate-elicited peritoneal exudate cells of wild-type and mutant mice. As shown in Figure $1 C$, mRNA for CCR2 was undetectable in $\mathrm{CCR} 2^{-1-}$ mice, whereas CCR5 mRNA was readily amplified in both wild-type and mutant mice. Since the genes encoding CCR 2 and CCR 5 are in close proximity in both humans and mice $(23,30)$, these results suggested that the targeting vector did not affect expression of neighboring genes in the chemokine receptor locus.

Recruitment of macrophages in response to inflammatory stimuli is impaired in CCR2 $2^{--}$mice. MCP-1 is a potent chemoattractant for monocytes both in vitro $(6,31,32)$ and in vivo $(33,34)$, and expression of MCP-1 is markedly induced by inflammatory stimuli $(35,36)$. To examine the role of CCR2 in an antigen-independent model of inflammation, we analyzed leukocytes elicited in response to intraperitoneal administration of thioglycollate in mutant and wild-type mice. Although significantly fewer thioglycollate-elicited cells were recovered from $\mathrm{CCR} 2^{-1-}$ mice than from wild-type and heterozygous mice, the number of resident macrophages was unaffected by deletion of CCR2 (Fig. $2 A$ ). The reduction in peritoneal exudate cells was largely accounted for by a significant decrease in the number of macrophages with little change in the absolute number of neutrophils, lymphocytes, eosinophils, or basophils
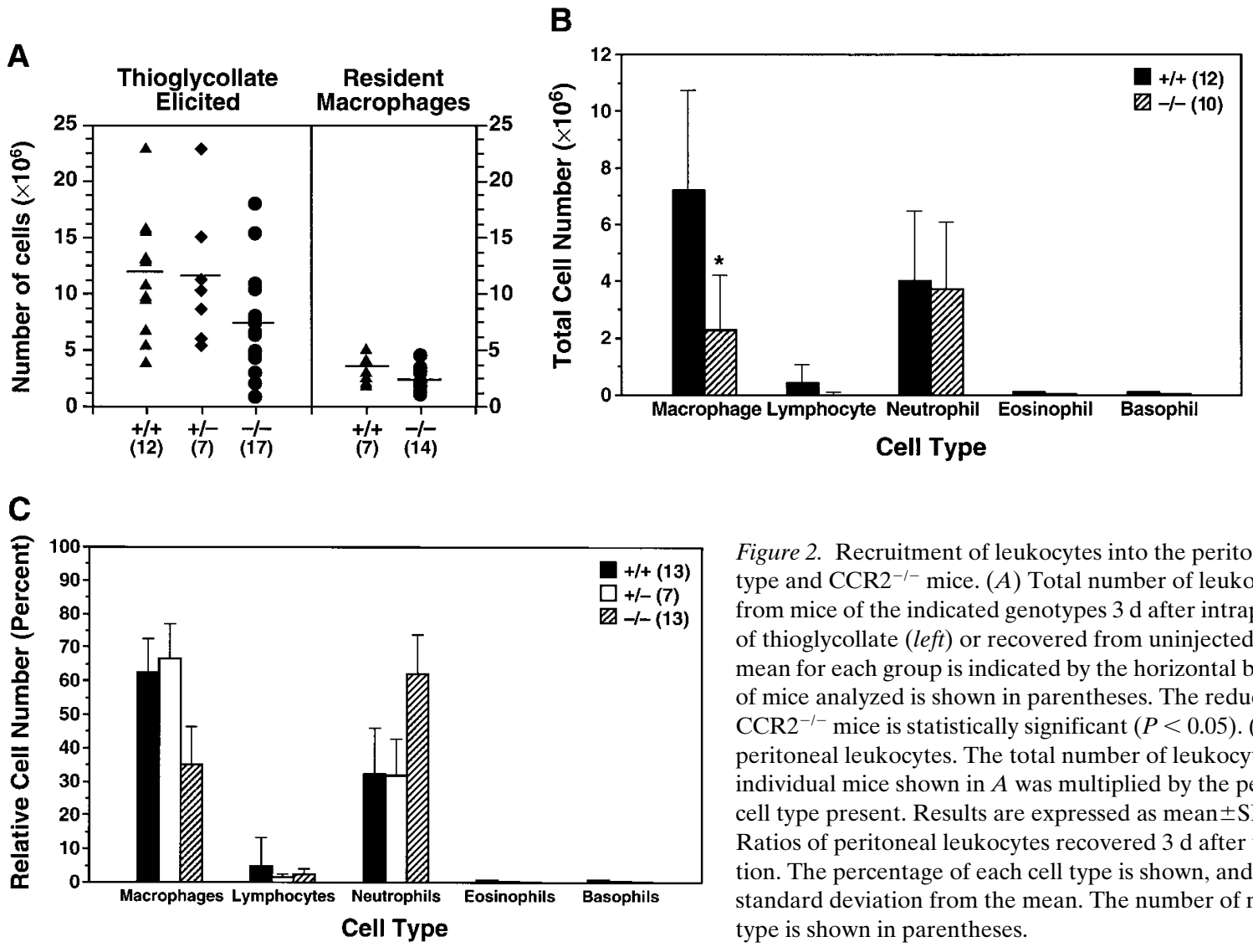

Figure 2. Recruitment of leukocytes into the peritoneal cavity of wildtype and CCR $2^{-l-}$ mice. $(A)$ Total number of leukocytes recovered from mice of the indicated genotypes $3 \mathrm{~d}$ after intraperitoneal injection of thioglycollate (left) or recovered from uninjected mice (right). The mean for each group is indicated by the horizontal bar, and the number of mice analyzed is shown in parentheses. The reduction observed in CCR2 $2^{-1-}$ mice is statistically significant $(P<0.05)$. (B) Quantitation of peritoneal leukocytes. The total number of leukocytes recovered from individual mice shown in $A$ was multiplied by the percentage of each cell type present. Results are expressed as mean \pm SD. $* P<0.05$. (C) Ratios of peritoneal leukocytes recovered $3 \mathrm{~d}$ after thioglycollate injection. The percentage of each cell type is shown, and error bars indicate standard deviation from the mean. The number of mice for each genotype is shown in parentheses. 
(Fig. $2 \mathrm{~B}$ ). The decrease in the number of macrophages resulted in an increase in the relative number of neutrophils, such that the ratio of inflammatory leukocytes was altered. Thus, in peritoneal exudate cells from $\mathrm{CCR} 2^{-/-}$mice, neutrophils were the predominant cell type (Fig. 2 C). These data suggest that the thioglycollate-induced accumulation of macrophages into the peritoneal cavity is dependent upon activation of CCR2. The most likely mechanism for this effect is upregulation of the expression of CCR2 agonists by peritoneal cells. We also examined leukocytes recruited into the peritoneum $18 \mathrm{~h}$ after thioglycollate injection and observed no difference in cell types between wild-type and $\mathrm{CCR} 2^{-/-}$mice; $>90 \%$ of the cells at this early time point were neutrophils (data not shown), suggesting that CCR2 does not play a role in the acute response to inflammation.

Chemotaxis of peritoneal exudate cells to MCP-1 and $M I P-1 \alpha$. We next tested macrophages from control and knockout mice for their ability to migrate in response to a chemotactic gradient of known mCCR2 ligands $(22,23)$. As shown in Fig. $3 \mathrm{~A}$, peritoneal exudate cells from $\mathrm{CCR} 2^{+/+}$and $\mathrm{CCR}_{2}^{+/-}$mice migrated in response to mMCP-1 (mJE) and mMCP-5, as well as to hMCP-1, with a characteristic biphasic dose-response curve. In contrast, peritoneal exudate cells from CCR2 $2^{-1-}$ mice had no chemotactic response to the CCR2 agonists. These data confirmed that the gene deleted in these studies is the endogenous MCP-1 receptor and that other closely related receptors do not provide a functional chemotactic response to MCP ligands. In contrast, peritoneal exudate cells from wild-type and $\mathrm{CCR} 2^{-/-}$mice migrated very similarly in response to MIP- $1 \alpha$, which interacts with chemokine receptors other than CCR2 (Fig. 3 B). This result indicates that CCR2 $2^{-/-}$ cells are not generally impaired in their ability to migrate to a chemotactic gradient.

Absence of myelosuppression by MCP-1 in myeloid progenitor cells from $C C R 2^{-/-}$mice. In vitro and in vivo, chemokines inhibit colony formation by myeloid progenitor cells $(16,28$, 37 ), suggesting that chemokines may negatively regulate the proliferative response of the immune system. To determine whether we had deleted the endogenous MCP-1 receptor in hematopoietic stem cells, we isolated progenitor cells from bone marrow, and measured CFU-GM in semisolid methylcellulose cultures. As shown in Fig. 4, mJE and human MCP-1, as well as other C-C and CXC chemokines (mMIP- $1 \alpha$, hIL- 8 ), inhibited CFU-GM formation by bone marrow cells isolated from wild-type mice. In contrast, CFU-GM formation by CCR2 $2^{-1-}$ cells was not inhibited by mJE or hMCP-1, whereas the inhibition observed with other chemokines was still intact. Similarly, murine and human MCP-1 also inhibited BFU-E and CFU-GEMM progenitors from $+/+$ mice, whereas proliferation of progenitors from $\mathrm{CCR} 2^{-/-}$mice was not inhibited (Table I). These data indicate that CCR2 is the endogenous receptor for MCP-1 in bone marrow progenitor cells. The absolute number of progenitors in the marrow, spleen, and peripheral blood of CCR2 $2^{-1-}$ mice was not altered (data not shown), and peripheral blood white cell counts, including monocytes, were also within the control range (Table II, Day 0). Taken together, these results suggest that CCR2 may not be required for normal myelopoiesis but may play a role in modulating the production of leukocytes during an immune response.

$C C R 2^{-1-}$ mice have functional defects in immune responses. To explore possible roles of MCP-1 signaling through CCR2 in an antigen-dependent model of inflammation, we in-
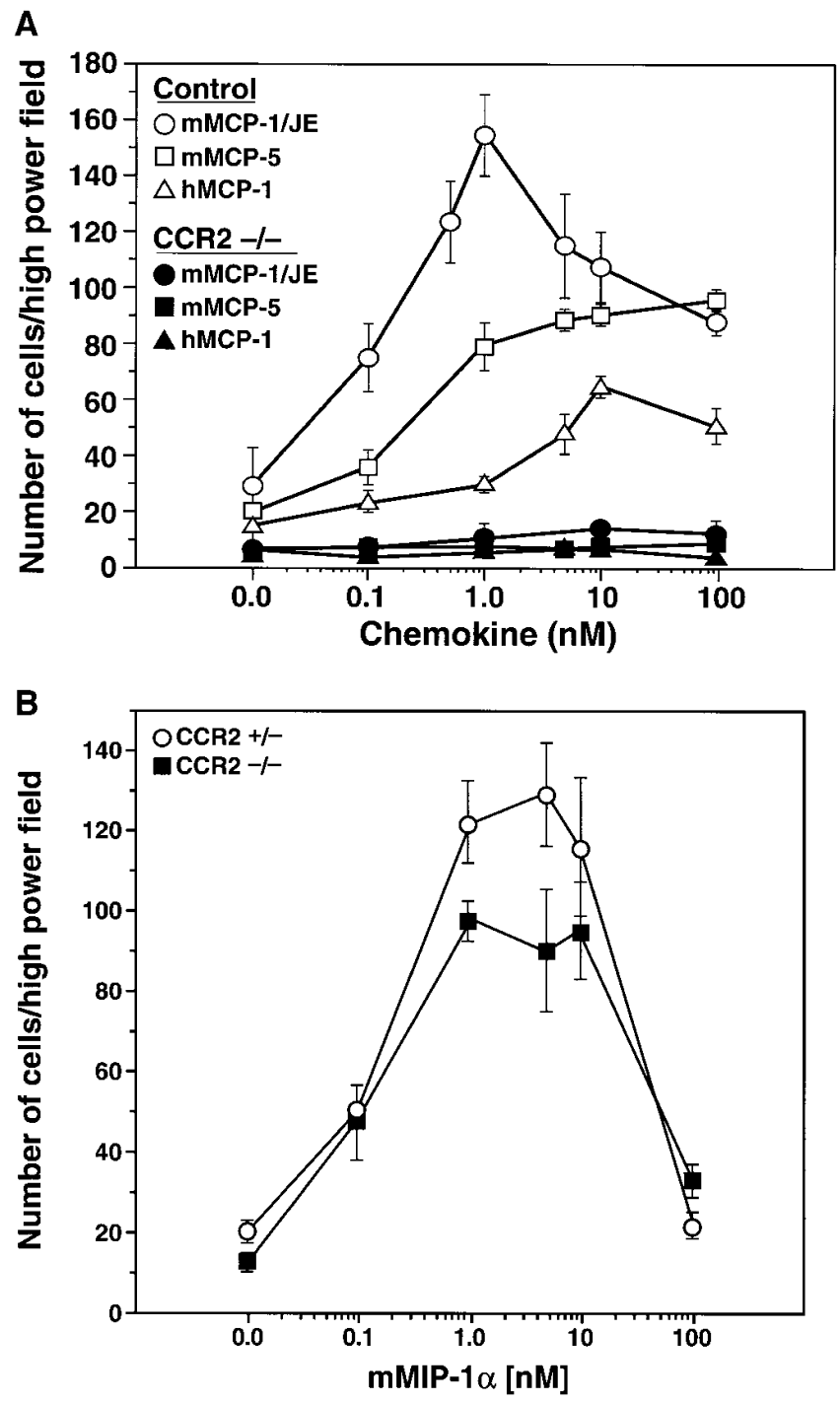

Figure 3. Chemotaxis of peritoneal leukocytes from control and mutant mice. $(A)$ Chemotaxis in response to MCP family chemokines. Cells were harvested $3 \mathrm{~d}$ after thioglycollate injection and incubated with increasing concentrations of MMCP-1/JE (circles), hMCP-1 (triangles), and mMCP-5 (squares). The number of control ( $+/+$ and $+/-$, open symbols) and mutant (-/-, filled symbols) cells migrating in response to each concentration of agonist was determined in triplicate, and data are presented as the mean \pm SD. Data shown are representative of three to six experiments. $(B)$ Chemotaxis in response to mMIP- $1 \alpha$. The number of $+/-$ (open circles) and $-/-$ (filled circles) peritoneal cells that migrated to each chemokine was determined as in $A$.

duced granulomas in the lungs of mice by injecting Sepharose beads coated with PPD from M. bovis. As previously reported (13), the response to PPD antigen in the mouse is associated with a Th1 cytokine profile in draining lymph node cells. Granuloma size and lymph node cytokine profiles were determined 2,4 , and $8 \mathrm{~d}$ after bead challenge. Granulomas from CCR2 $2^{-1-}$ mice were significantly smaller than those from wild-type mice at day 4, but not on day 2 or 8 (Fig. 5), and the absolute number of macrophages in these granulomas was reduced by 75 and $42 \%$ on days 2 and 4 , respectively, but no reduction was detected by day 8 (data not shown). The number of lympho- 

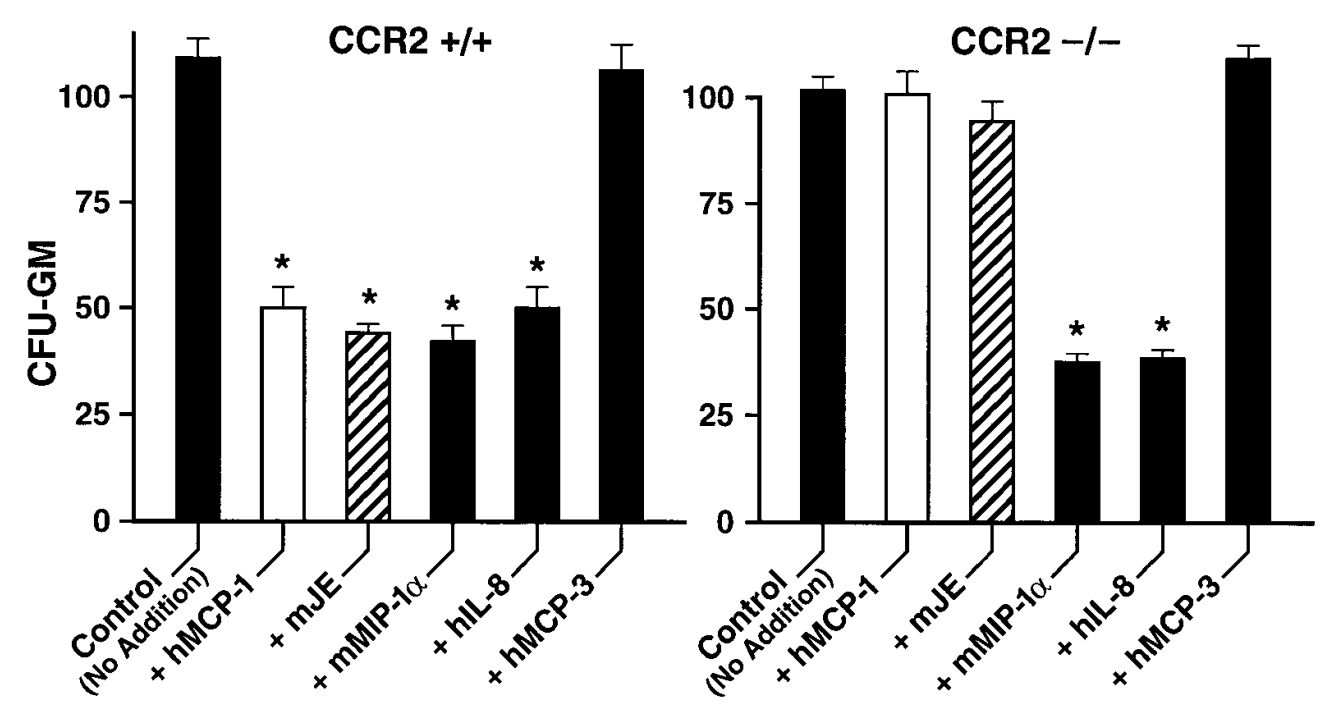

Figure 4. Inhibition of colony formation by myeloid progenitor cells in wild-type and CCR2 $2^{-1-}$ mice. Bone marrow cells were cultured in methylcellulose plus growth factors with or without chemokines as described in Methods. Colony formation $(C F U$ - $G M)$ by $5 \times 10^{4}$ cells $/ \mathrm{ml}$ pooled from $+1+(n=3)$ and $-/-(n=5)$ mice. $* P<0.05$ versus control medium.

cytes, eosinophils, and neutrophils was unchanged. These data suggest that CCR2 agonists are required for the initial recruitment of macrophages into granulomatous lesions, but that other cytokines are predominantly responsible for recruitment at later time points. In wild-type mice, PPD challenge increased the number of circulating monocytes (to $8-10 \%$, Table II). In contrast, in the $\mathrm{CCR} 2^{-1-}$ mice this monocytosis did not occur, and the number of circulating blood monocytes remained low at all time points $(1-4 \%$, Table II). Thus, the decreased number of macrophages recruited to granulomas on days 2 and 4 may result in part from a smaller pool of circulating monocytes.

Decreased IFN- $\gamma$ production in $C C R 2^{-/-}$mice. To address the role of CCR2 in cytokine production after antigenic challenge, draining lymph nodes were harvested 2, 4, and $8 \mathrm{~d}$ after infusion of PPD-coupled beads and maintained in culture. Lymph node cells from wild-type mice produced readily de-

Table I. Effects of Chemokines on Colony Formation by Myeloid Progenitor Cells from Bone Marrow of Wild-Type and $C C R 2^{-/-}$Mice*

\begin{tabular}{llllll}
\hline & \multicolumn{2}{c}{ BFU-E } & & \multicolumn{2}{c}{ CFU-GEMM } \\
\cline { 2 - 3 } \cline { 5 - 6 } \multicolumn{1}{c}{ Chemokines } & $+1+$ & $-1-$ & & $+/+$ & $-/-$ \\
\hline Control Medium & $23 \pm 2$ & $25 \pm 3$ & & $6 \pm 1$ & $7 \pm 1$ \\
hMCP-1 & $16 \pm 2^{\ddagger}$ & $23 \pm 0.3$ & & $3 \pm 0.6^{\ddagger}$ & $8 \pm 1$ \\
mMCP-1 (JE) & $15 \pm 0.3^{\ddagger}$ & $24 \pm 3$ & & $3 \pm 0.3^{\ddagger}$ & $8 \pm 0.6$ \\
mMIP-1 $\alpha$ & $16 \pm 1^{\ddagger}$ & $11 \pm 0.3^{\ddagger}$ & & $4 \pm 0.3^{\ddagger}$ & $2 \pm 0.3^{\ddagger}$ \\
hIL-8 & $17 \pm 2^{\ddagger}$ & $11 \pm 2^{\ddagger}$ & & $4 \pm 1^{\ddagger}$ & $3 \pm 0.6^{\ddagger}$ \\
hIP-10 & $14 \pm 2^{\ddagger}$ & $11 \pm 1^{\ddagger}$ & & $3 \pm 0.6^{\ddagger}$ & $4 \pm 1^{\ddagger}$ \\
mMIP-2 & $17 \pm 2^{\ddagger}$ & $13 \pm 1^{\ddagger}$ & & $4 \pm 0.3^{\ddagger}$ & $3 \pm 0.6^{\ddagger}$ \\
hMCP-2 & $28 \pm 1$ & $26 \pm 0.6$ & & $7 \pm 0.3$ & $8 \pm 1$ \\
hMCP-3 & $26 \pm 1$ & $26 \pm 2$ & & $7 \pm 0.6$ & $7 \pm 0.6$ \\
hGRO- $\alpha$ & $29 \pm 3$ & $26 \pm 3$ & & $8 \pm 2$ & $8 \pm 2$ \\
hNAP-2 & $27 \pm 2$ & $25 \pm 2$ & & $7 \pm 0.6$ & $8 \pm 0.6$ \\
& & & & & \\
\hline
\end{tabular}

* Colony formation by $5 \times 10^{4}$ bone marrow cells pooled from wild-type $(+/+)(n=3)$ and mutant $(-/-)(n=5)$ mice. Results are expressed as mean \pm SEM. ${ }^{\ddagger} P<0.05$ compared to control medium. tectable amounts of IL-2 and IFN- $\gamma$ when re-exposed to PPD (Fig. 6). In contrast, the large increase in IFN- $\gamma$ production that occurred on days 4 and 8 was not observed in lymph node cells from CCR2 ${ }^{-/-}$mice. IL-12 (p35/40), which promotes IFN- $\gamma$ production (for a review, see reference 38 ), was barely detectable in cultures of both wild-type and CCR2 $2^{-1-}$ lymph node cells, and expression of Th2 cytokines (IL-4 and IL-5) was also low and not significantly different between the two genotypes (data not shown). These data suggest that CCR2 is required for maximal generation of IFN- $\gamma$-producing cells during a type 1 immune response.

To further characterize the defect leading to decreased IFN- $\gamma$ production, we isolated $T$ cells from the spleens of wildtype and $\mathrm{CCR} 2^{-1-}$ mice $4 \mathrm{~d}$ after exposure to PPD. As seen in Fig. $7 A$, virtually no IFN- $\gamma$ was produced unless the cells were rechallenged with PPD. After re-exposure to PPD, there was a robust response in the $\mathrm{CCR}^{+/+}$cells, and this was increased about twofold by the addition of APC. There was no differ-

Table II. Blood Leukocyte Differentials in Wild-Type and CCR2 ${ }^{-}{ }^{-}$Mice with PPD-induced Granulomas

\begin{tabular}{lccccc}
\hline & & \multicolumn{4}{c}{ Cell type (\%) } \\
\cline { 3 - 6 } & Genotype & Lymphocyte & Monocyte & Eosinophil & Neutrophil \\
\hline Day 0* & $+/+$ & $89.7 \pm 6.1$ & $2.0 \pm 0.8$ & $1.2 \pm 1.2$ & $7.0 \pm 6.3$ \\
& $-/-$ & $88.3 \pm 2.1$ & $2.0 \pm 1.7$ & $1.3 \pm 1.1$ & $8.3 \pm 3.0$ \\
Day 2 & $+/+$ & $43.7 \pm 21.6$ & $10.4 \pm 3.6$ & $2.2 \pm 2.0$ & $43.3 \pm 20.0$ \\
& $-/-$ & $59.2 \pm 10.2$ & $2.9 \pm 2.5^{\ddagger}$ & $1.2 \pm 1.5$ & $36.2 \pm 9.0$ \\
Day 4 & $+/+$ & $69.7 \pm 14.0$ & $8.0 \pm 1.2$ & $3.3 \pm 1.2$ & $19.1 \pm 15.4$ \\
& $-/-$ & $69.0 \pm 14.7$ & $4.0 \pm 0.1^{\ddagger}$ & $1.4 \pm 1.6$ & $35.7 \pm 15.0$ \\
Day 8 & $+/+$ & $69.3 \pm 15.0$ & $8.5 \pm 4.2$ & $1.5 \pm 1.3$ & $20.7 \pm 9.6$ \\
& $-/-$ & $74.3 \pm 9.7$ & $0.7 \pm 0.6^{\ddagger}$ & $2.0 \pm 0.9$ & $22.7 \pm 9.7$
\end{tabular}

Total blood leukocyte differentials were determined for three mice of each genotype at each time point after challenge with PPD-coated beads. Values are mean \pm SD. $*$ Naive mice. ${ }^{\ddagger} P<0.05$ compared to $+/+$ mice. 

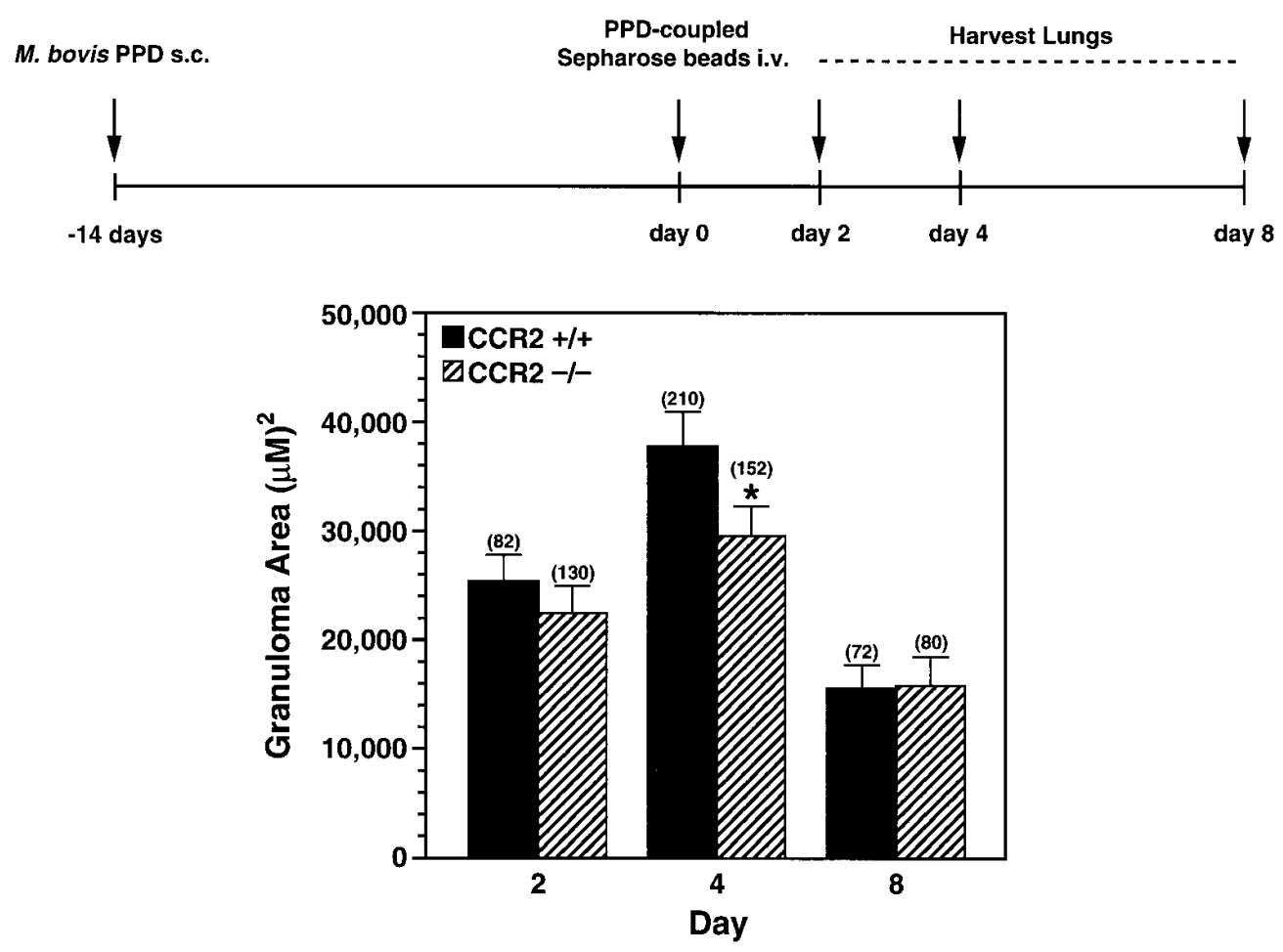

Figure 5. Size of PPD-induced granulomas in wild-type and $\mathrm{CCR} 2^{-1-}$ mice. Lungs were fixed 2,4 , and $8 \mathrm{~d}$ after challenge with PPD-coated beads, and granuloma area was determined from paraffin-embedded sections as described in Methods. The number of granulomas measured, pooled from three or four mice for each time point, is indicated in parentheses. ${ }^{*} P<0.05$.

ence between APCs from wild-type versus CCR2 $2^{-1-}$ mice. In contrast, IFN- $\gamma$ production by $\mathrm{T}$ cells from $\mathrm{CCR} 2^{-1-}$ mice was almost undetectable, and this response was not restored by the addition of wild-type APC (Fig. $7 A$ ). In parallel experiments, PPD-stimulated IL-2 expression from CCR2 $2^{-1-} \mathrm{T}$ cells was also decreased, though not as greatly as IFN- $\gamma$ expression (Fig. $7 \mathrm{~B}$ ). These data indicate that $\mathrm{T}$ cells from the spleens of $\mathrm{CCR} 2^{-1-}$ mice have profound defects in antigen-dependent production of cytokines, particularly IFN- $\gamma$. These data also indicate that APC from $\mathrm{CCR} 2^{-1-}$ mice have normal antigenpresenting function.

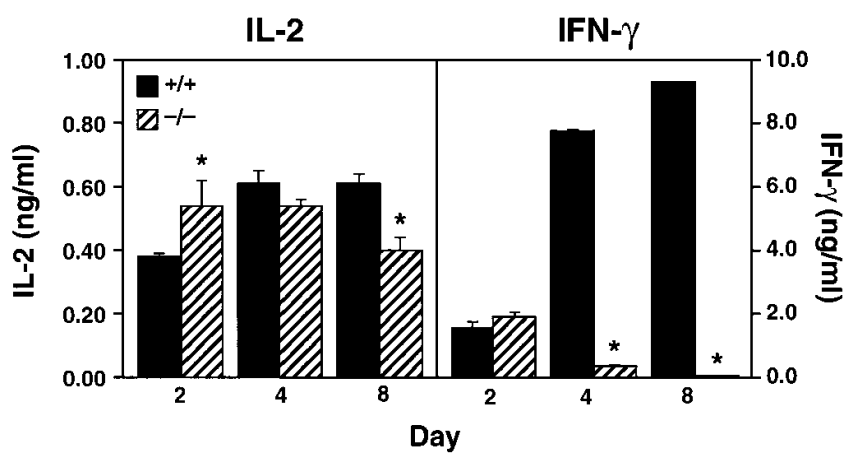

Figure 6. Cytokine profiles of draining lymph node cells from PPDbead-challenged $\mathrm{CCR} 2^{+/+}$and $\mathrm{CCR} 2^{-/-}$mice. Lymph nodes were harvested 2, 4, and $8 \mathrm{~d}$ after granuloma induction, dispersed into single cells, and cultured with $5 \mu \mathrm{g} / \mathrm{ml}$ of PPD. Cytokine levels were determined by ELISA $24 \mathrm{~h}$ later. Cytokine production in the absence of PPD was undetectable. Values represent mean \pm SD of triplicate determinations of lymph node cells pooled from three mice for each time point. $* P<0.05$.
Decreased IFN- $\gamma$ production in CCR2 ${ }^{-/-}$ConA-stimulated splenocytes. To determine whether CCR 2 was directly involved in the production of Th1 cytokines or alternatively whether the decreased cytokine production was due to an indirect effect, such as differences in leukocyte trafficking or lymphocyte development in $\mathrm{CCR} 2^{-/-}$mice, spleen cells from naive mice were stained with antibodies specific for $\mathrm{T}$ cells, $\mathrm{B}$ cells, and macrophages and analyzed by flow cytometry. No significant differences were observed between $+/+$ and $-/-$ mice in the expression of CD3, CD4, and CD8 (T cell markers), B220 and IgM (B cells), or CD11b (macrophages and neutrophils) (data not shown). We next used ConA, a potent polyclonal activator of $\mathrm{T}$ cells, to stimulate IFN- $\gamma$ production by naive splenocytes. As seen in Fig. 8, ConA induced high levels of IFN- $\gamma$ production by splenocytes from wild-type mice, but this response was reduced by $60 \%$ in CCR $2-/-$ mice. In contrast, splenocytes from the CCR2-deficient mice produced significantly more IL-2 than those of wild-type animals, indicating that cells from $\mathrm{CCR}^{-/-}$mice were not generally defective in cytokine production. These results suggest that the decrease in IFN- $\gamma$ expression by $\mathrm{CCR} 2^{-1-} \mathrm{T}$ cells is not simply a result of defects in lymphocyte trafficking to lymphoid tissue. Since splenocytes contain both APC and T cells, these experiments do not reveal which cell type(s) require CCR2.

\section{Discussion}

In this study, we have used homologous recombination in ES cells to generate mice that are genetically deficient for the chemokine receptor CCR2. The $\mathrm{CCR} 2^{-1-}$ mice were viable, developed normally, and showed no overt morphological or behavioral defects. Examination of the hematopoietic system revealed no defects in the number of myeloid progenitor cells 
A

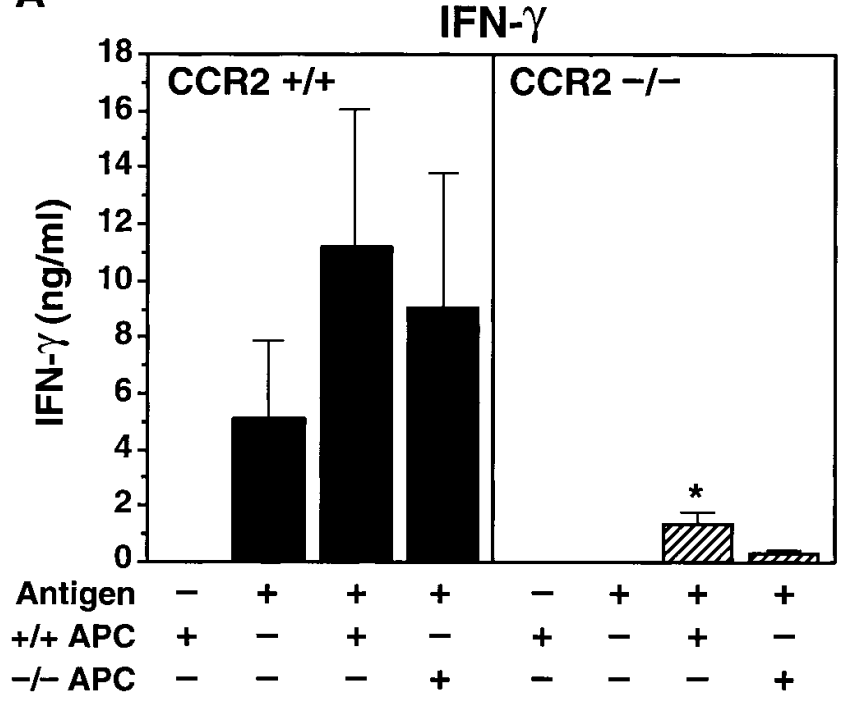

B

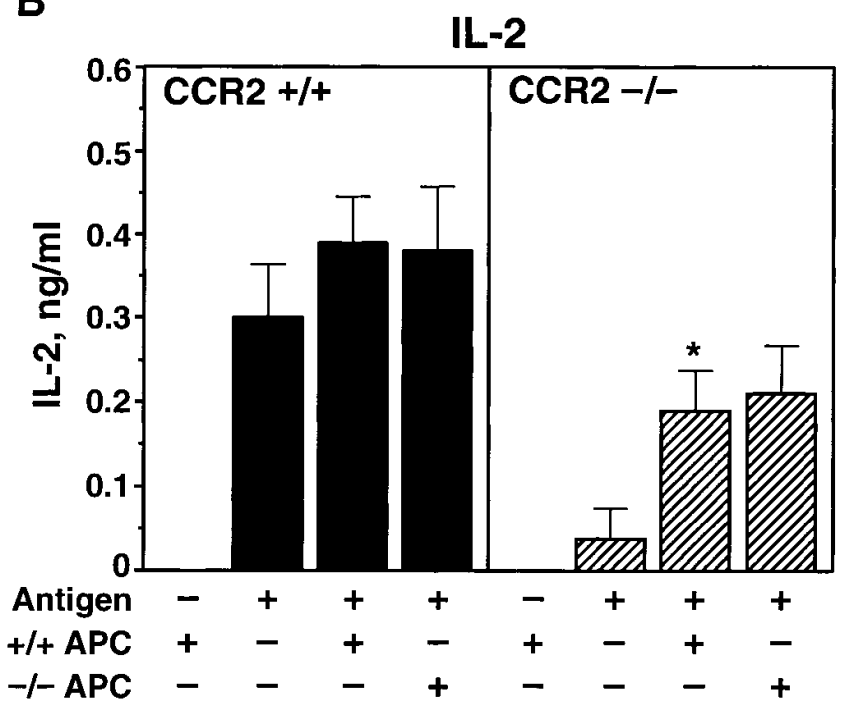

Figure 7. Cytokine production by $\mathrm{T}$ cells from PPD-challenged wildtype and CCR2 $2^{-1-}$ mice. ( $A$ ) IFN- $\gamma$. (B) IL-2. T lymphocytes and APC were isolated from the spleens of wild-type (left) and CCR2 $2^{-1-}$ mice (right) $4 \mathrm{~d}$ after granuloma induction, cultured in the presence or absence of PPD $(5 \mu \mathrm{g} / \mathrm{ml}$ antigen $)$, and cytokine levels were measured after $24 \mathrm{~h}$. Cytokine levels in control cultures (before depletion of APC) were similar to those in which purified APC were added back to isolated T cells (data not shown). Values represent means and $95 \%$ confidence levels for four individual mice of each genotype. $* P<0.05$.

or in the development of lymphocyte subsets. Although the mice exhibited no obvious phenotype in the unstressed state, exposure to both antigenic and nonantigenic challenges revealed significant defects in monocyte/macrophage recruitment and immunological responses, most notably a profound impairment in IFN- $\gamma$ production. These data indicate that activation of CCR 2 by MCP-1 and related chemokines is critically involved in recruiting macrophages at sites of inflammation, and support an important role for CCR2 in modulating the immune response and cytokine production.
In humans, there are two well-characterized receptors for MCP-1, CCR2A, and CCR2B, which are splice variants of a single gene (39). In the mouse, we have detected only a single MCP-1 receptor (23). The targeting strategy used in this study would also have eliminated splice variants of murine CCR2 if they existed. Several lines of evidence indicated that the endogenous functional MCP-1 receptor was deleted in $\mathrm{CCR} 2^{-/-}$ mice. First, thioglycollate-elicited peritoneal leukocytes from $\mathrm{CCR} 2^{-1-}$ mice had a selective defect in their ability to migrate towards MCP-1 and other known CCR2 ligands, but responded well to MIP-1 $\alpha$. Similar results were obtained with casein-elicited peritoneal leukocytes (Boring, L., unpublished observations). Second, both murine and human MCP-1 suppressed myelopoiesis in wild-type mice but not in $\mathrm{CCR} 2^{-/-}$ mice. Finally, recruitment of macrophages into the peritoneum of CCR2 $2^{-1-}$ mice was markedly impaired after an inflammatory insult, a result very similar to that observed in the mMCP-1 (JE) knockout mouse (Rollins, B.J., personal communication).

Given the high degree of both structural similarity and in vitro responses of leukocytes to $\mathrm{C}$ - $\mathrm{C}$ chemokines, significant redundancy of function was likely to be present in vivo. It was thus somewhat surprising that deletion of CCR2 led to a profound defect in the recruitment of leukocytes into the peritoneum. This result indicated that in vivo, MCP-1 signaling through CCR2 provides a unique function. Nonredundant chemokine functions were also observed in MIP- $1 \alpha$-deficient mice, which were resistant to coxsackievirus-induced myocarditis (40).

Using an antigen-dependent model of lung inflammation, we found that CCR2 played a role in both granuloma induction and modulation of the immune response. In $\mathrm{CCR} 2^{-1-}$ mice, PPD-induced lung granulomas were significantly reduced in size $4 \mathrm{~d}$ after bead challenge, and this reduction was accompanied by a selective decrease in macrophage recruitment into the granulomas on days 2 and 4 . This result provides further evidence that CCR2 participates in the recruitment of monocytes/macrophages to sites of inflammation. That the macrophage content of the granulomas returned to control levels at later time points in the $\mathrm{CCR} 2^{-/-}$mice indicated that receptors other than CCR2 also mediate monocyte recruit-

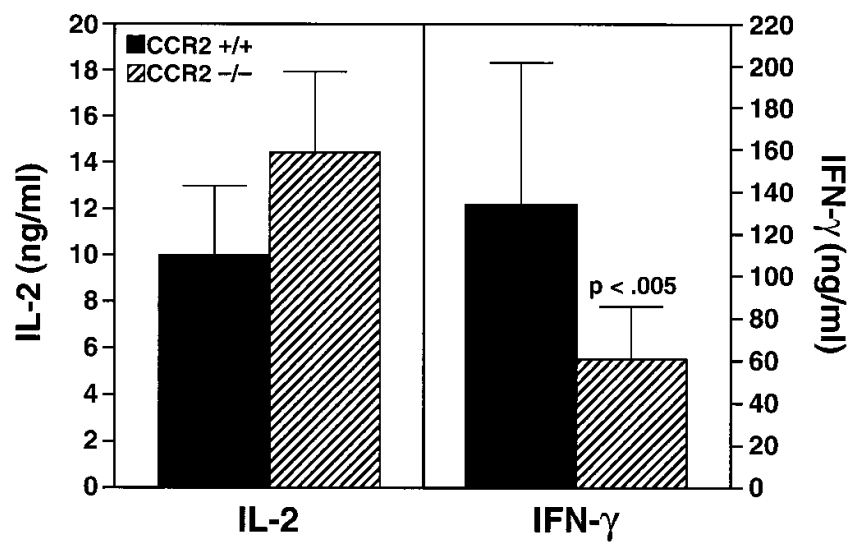

Figure 8. Cytokine production by ConA-stimulated naive splenocytes from wild-type and CCR2 $2^{-1-}$ mice. Spleens from unchallenged mice were dispersed in culture and stimulated with ConA $(5 \mu \mathrm{g} / \mathrm{ml})$. Cytokine levels were measured $24 \mathrm{~h}$ later. Values represent means and standard deviation from six individual mice for each genotype. 
ment. PPD bead challenge also resulted in a marked monocytosis in wild-type mice but not in the $\mathrm{CCR} 2^{-1-}$ mice. These data suggest that antigen-induced monocyte recruitment into the circulation, as was found for thioglycollate-induced recruitment into the peritoneum, is highly dependent on activation of CCR2. The failure of the CCR2 $2^{-/-}$mice to develop monocytosis may partially explain the decreased macrophage content of the induced granulomas.

Lung granulomas induced by $M$. bovis PPD are associated with a Th1 (IL-2, IFN- $\gamma$ ) cytokine response. Several lines of evidence indicate that CCR2 is necessary for robust IFN- $\gamma$ production in PPD-challenged mice. First, examination of cytokine profiles by draining lymph node cells from $\mathrm{CCR} 2^{-/-}$ mice revealed impaired IFN- $\gamma$ production, whereas the wild-type mice showed a large, time-dependent increase in this cytokine. Second, $\mathrm{T}$ cells isolated from PPD-sensitized CCR2 $2^{-1-}$ mice had a dramatic reduction in PPD-induced IFN- $\gamma$ production and, to a lesser extent, reduced IL-2 production. This reduction was not corrected by inclusion of wild-type APCs, indicating that the genotype of the T cells, rather than the APCs, was critical in mediating upregulation of IFN- $\gamma$. It is noteworthy that the reductions in IFN- $\gamma$ and IL-2 were not apparent in lymph node cells at day 2, presumably the early stage of $\mathrm{T}$ cell activation. Thus, we speculate that CCR2 is involved in promoting $\mathrm{T}$ cell maturation beyond the IL-2-producing stage.

There is increasing evidence that chemokines participate in the differentiation of lymphocytes towards Th1- or Th2-type phenotypes. Taub et al. found that chemokines act as costimulators and enhance IL-2 production by T cell clones (15). Using lymphocytes derived from $\mathrm{T}$ cell receptor transgenic mice, Karpus et al. (41) demonstrated that chemokines induced distinct cytokine profiles upon exposure of naive cells to the antigen. Cells stimulated through the $\mathrm{T}$ cell receptor and incubated in the presence of MIP- $1 \alpha$ had enhanced IFN- $\gamma$ production, whereas cells incubated in the presence of MCP-1 had enhanced IL-4 production. In earlier studies, these investigators provided in vivo data suggesting that MIP- $1 \alpha$ played a role in the pathogenesis of Th1-dependent experimental autoimmune encephalomyelitis (42), whereas MCP-1 was involved in mediating oral tolerance (43). Taken together, these data suggested that MCP-1 contributed primarily to the development of the Th2 phenotype, whereas exposure to MIP-1 $\alpha$ led to a Th1 phenotype. Consistent with this, we have previously found that use of a neutralizing antibody to MCP-1 was more effective in reducing the size of schistosome egg antigen-induced granulomas, which are associated with a Th2 response, than PPDinduced lesions (13). Results reported in the current paper, however, support a role for MCP-1 in the development of a Th1 response. There are several possible explanations for why other studies have failed to reveal a role for MCP-1/CCR2 in Th1 responses. First, much of the earlier data was obtained by using neutralizing antibodies to block MCP-1, and the blockade may not have been complete. Second, there are at least two more recently described ligands for CCR2 in the mouse (MCP-3 = Marc/fic [44] and MCP-5 [22]), and it is not clear if the MCP-1 antibodies also neutralized these chemokines. Third, complete congenital absence of CCR2 may influence the status of other cells, such as natural killer and mast cells, that potentially participate in immune regulation and thereby alter normal lymphocyte maturational pathways. The use of homologous recombination to delete CCR2 has revealed a novel role for MCP-1 (and possibly MCP-3 and MCP-5) in regulating the immune response to PPD and perhaps other antigens that induce delayed-type hypersensitivity. Studies to determine if Th2 responses (e.g., schistosome egg antigen-induced granuloma formation) are altered in the $\mathrm{CCR}^{-1-}$ mouse are currently in progress.

The decrease in IFN- $\gamma$ production seen in the PPD model may reflect either a direct effect of MCP-1/CCR2 on T cells or an indirect effect, such as CCR2-dependent lymphocyte trafficking to lymph nodes or spleen. No differences in the total numbers of lymphocytes between wild-type and $\mathrm{CCR} 2^{-1-}$ mice were seen; nor were there any differences between subsets of T cells, B cells, or macrophages between the two groups. These results make it less likely that the data can be explained by trafficking defects of either T cells or APCs. It was still possible, however, that fewer PPD-reactive T cells were available in the spleens of knockout versus wild-type animals. To address this possibility, we used ConA to activate naive splenocytes. As was found with PPD, cells from $\mathrm{CCR} 2^{-1-}$ mice produced far less IFN- $\gamma$ in response to ConA than did wild-type littermate controls. These results suggest that CCR2 is required for IFN- $\gamma$ production by spleen cells and imply that splenocytes produce MCP-1 in response to ConA stimulation. In preliminary experiments, we have indeed found ConA-dependent production of MCP-1 in the conditioned media of these cultures and further noted that MCP-1 levels are reduced in the $\mathrm{CCR}^{-/-}$cells (Chensue, S., unpublished data). Further experiments will be required to determine which cell type(s) secrete and respond to MCP-1.

Previous studies have shown that cytokines regulate expression of chemokine receptors, including CCR2 (45). Our results indicate that chemokine receptor expression also regulates cytokine expression and lymphocyte differentiation towards Th1 or Th2 phenotypes. Elucidating the signal transduction pathways responsible for this differentiation and assessing the potential for selectively controlling the development of such lymphocyte phenotypes represent exciting areas of future investigation.

\section{Acknowledgments}

We thank Heather Myers for assistance in embryonic stem cell culture, Eric Sande for blastocyst injections, and Kelly Warmington and Jeff Ruth for technical assistance with the lung granuloma model. We also thank John Carroll, Amy Corder, Brian Clark, and Stephen Gonzalez for graphics and photography assistance, Gary Howard and Stephen Ordway for editorial assistance, and Angela Chen for manuscript preparation.

This work was supported in part by National Institutes of Health grants HL-52773 (to I.F. Charo) and DK-53674 and HL-56416 (to H.E. Broxmeyer).

\section{References}

1. Murphy, P.M. 1994. The molecular biology of leukocyte chemoattractant receptors. Annu. Rev. Immunol. 12:593-633.

2. Schall, T.J. 1994. The chemokines. In The Cytokine Handbook. 2nd ed. A.W. Thomson, editor. Academic Press, London. 419-460.

3. Gerard, C., and N.P. Gerard. 1994. C5a anaphylatoxin and its seven transmembrane-segment receptor. Annu. Rev. Immunol. 12:775-808.

4. Baggiolini, M., B. Dewald, and B. Moser. 1997. Human chemokines: an update. Annu. Rev. Immunol. 15:675-705.

5. Hedrick, J.A., and A. Zlotnik. 1996. Chemokines and lymphocyte biology. Curr. Opin. Immunol. 8:343-347.

6. Furutani, Y., H. Nomura, M. Notake, Y. Oyamada, T. Fukui, M. Yamada, C.G. Larsen, J.J. Oppenheim, and K. Matsushima. 1989. Cloning and sequencing of the cDNA for human monocyte chemotactic and activating factor 
(MCAF). Biochem. Biophys. Res. Commun. 159:249-255.

7. Carr, M.W., S.J. Roth, E. Luther, S.S. Rose, and T.A. Springer. 1994. Monocyte chemoattractant protein 1 acts as a T-lymphocyte chemoattractant. Proc. Natl. Acad. Sci. USA. 91:3652-3656.

8. Kuna, P., S.R. Reddigari, T.J. Schall, D. Rucinski, M. Sadick, and A.P. Kaplan. 1993. Characterization of the human basophil response to cytokines, growth factors, and histamine releasing factors of the intercrine/chemokine family. J. Immunol. 150:1932-1943.

9. Ylä-Herttuala, S., B.A. Lipton, M.E. Rosenfeld, T. Särkioja, T. Yoshimura, E.J. Leonard, J.L. Witztum, and D. Steinberg. 1991. Expression of monocyte chemoattractant protein 1 in macrophage-rich areas of human and rabbit atherosclerotic lesions. Proc. Natl. Acad Sci. USA. 88:5252-5256.

10. Ross, R. 1993. The pathogenesis of atherosclerosis: a perspective for the 1990s. Nature. 362:801-809.

11. Nelken, N.A., S.R. Coughlin, D. Gordon, and J.N. Wilcox. 1991. Monocyte chemoattractant protein-1 in human atheromatous plaques. J. Clin. Invest. 88:1121-1127.

12. Koch, A.E. S.L. Kunkel, L.A. Harlow, B. Johnson, H.L. Evanoff, G.K. Haines, M.D. Burdick, R.M. Pope, and R.M. Strieter. 1992. Enhanced production of monocyte chemoattractant protein-1 in rheumatoid arthritis. J. Clin. Invest. 90:772-779.

13. Chensue, S.W., K.S. Warmington, J.H. Ruth, P.S. Sanghi, P. Lincoln, and S.L. Kunkel. 1996. Role of monocyte chemoattractant protein-1 (MCP-1) in Th1 (mycobacterial) and Th2 (schistosomal) antigen-induced granuloma formation. Relationship to local inflammation, Th cell expression, and IL-12 production. J. Immunol. 157:4602-4608.

14. Taub, D.D., K. Conlon, A.R. Lloyd, J.J. Oppenheim, and D.J. Kelvin. 1993. Preferential migration of activated $\mathrm{CD}^{+}$and $\mathrm{CD}^{+} \mathrm{T}$ cells in response to MIP-1 $\alpha$ and MIP-1ß. Science. 260:355-358.

15. Taub, D.D., J.R. Ortaldo, S.M. Turcovski-Corrales, M.L. Key, D.L. Longo, and W.J. Murphy. 1996. $\beta$ Chemokines costimulate lymphocyte cytolysis, proliferation, and lymphokine production. J. Leukocyte Biol. 59:81-89.

16. Broxmeyer, H.E., S. Cooper, N. Hague, L. Benninger, A. Sarris, K. Cornetta, S. Vadhan-Raj, P. Hendrie, and C. Mantel. 1995. Human chemokines: enhancement of specific activity and effects in vitro on normal and leukemic progenitors and a factor-dependent cell line and in vivo in mice. Ann. Hematol. 71:235-246.

17. Charo, I.F., S.J. Myers, A. Herman, C. Franci, A.J. Connolly, and S.R. Coughlin. 1994. Molecular cloning and functional expression of two monocyte chemoattractant protein 1 receptors reveals alternative splicing of the carboxylterminal tails. Proc. Natl. Acad. Sci. USA. 91:2752-2756.

18. Franci, C., L.M. Wong, J. Van Damme, P. Proost, and I.F. Charo. 1995. Monocyte chemoattractant protein-3, but not monocyte chemoattractant protein-2, is a functional ligand of the human monocyte chemoattractant protein-1 receptor. J. Immunol. 154:6511-6517.

19. Combadiere, C. S.K. Ahuja, J. Van Damme, H.L. Tiffany, J.-L. Gao, and P.M. Murphy. 1995. Monocyte chemoattractant protein-3 is a functional ligand for CC chemokine receptors 1 and 2B. J. Biol. Chem. 270:29671-29675.

20. Garcia-Zepeda, E.A., C. Combadiere, M.E. Rothenberg, M.N. Sarafi, F. Lavigne, Q. Hamid, P.M. Murphy, and A.D. Luster. 1996. Human monocyte chemoattractant protein (MCP)-4 is a novel CC chemokine with activities on monocytes, eosinophils, and basophils induced in allergic and nonallergic inflammation that signals through the CC chemokine receptors (CCR)-2 and -3 . J. Immunol. 157:5613-5626.

21. Stellato, C., P. Collins, P.D. Ponath, D. Soler, W. Newman, G. La Rosa, H. Li, J. White, L.M. Schwiebert, C. Bickel, et al. 1997. Production of the novel C-C chemokine MCP-4 by airway cells and comparison of its biological activity to other C-C chemokines. J. Clin. Invest. 99:926-936.

22. Sarafi, M.N., E.A. Garcia-Zepeda, J.A. MacLean, I.F. Charo, and A.D. Luster. 1997. Murine monocyte chemoattractant protein (MCP)-5: a novel CC chemokine that is a structural and functional homologue of human MCP-1. J. Exp. Med. 185:99-109.

23. Boring, L., J. Gosling, F.S. Monteclaro, A.J. Lusis, C.-L. Tsou, and I.F. Charo. 1996. Molecular cloning and functional expression of murine JE (monocyte chemoattractant protein 1 ) and murine macrophage inflammatory protein $1 \alpha$ receptors. Evidence for two closely linked C-C chemokine receptors on chromosome 9. J. Biol. Chem. 271:7551-7558.

24. Ishibashi, S., M.S. Brown, J.L. Goldstein, R.D. Gerard, R.E. Hammer, and J. Herz. 1993. Hypercholesterolemia in low density lipoprotein receptor knockout mice and its reversal by adenovirus-mediated gene delivery. J. Clin. Invest. 92:883-893.

25. Meiner, V.L., S. Cases, H.M. Myers, E.R. Sande, S. Bellosta, M. Schambelan, R.E. Pitas, J. McGuire, J. Herz, and R.V. Farese, Jr. 1996. Disruption of the acyl-CoA:cholesterol acyltransferase gene in mice: evidence suggesting multiple cholesterol esterification enzymes in mammals. Proc. Natl. Acad. Sci. USA. 93:14041-14046.

26. Mage, M.G., L.L. McHugh, and T.L. Rothstein. 1977. Mouse lymphocytes with and without surface immunoglobulin: preparative scale separation in polystyrene tissue culture dishes coated with specifically purified anti-immunoglobulin. J. Immunol. Methods. 15:47-56.

27. Hathcock, K.S., A. Singer, and R.J. Hodes. 1981. Passage over sephadex G-10 columns. In Manual of Macrophage Methodology: Collection, Characterization and Function. H.H. Herskowitz, H.T. Holden, J.A. Eelanti, and A Ghaffer, editors. Marcel Dekker, New York. 127-133.

28. Maze, R., B. Sherry, B.S. Kwon, A. Cerami, and H.E. Broxmeyer. 1992. Myelosuppressive effects in vivo of purified recombinant murine macrophage inflammatory protein-1 $\alpha . J$. Immunol. 149:1004-1009.

29. Kruisbeek, A.M. 1992. Isolation of mouse mononuclear cells. In Current Protocols in Immunology. J.E. Coligan, A.M. Kruisbeek, D.H. Margulies, E.M Shevach, and W. Strober, editors. Greene Publishing and Wiley-Interscience, New York. 3.1.2-3.1.5.

30. Raport, C.J., J. Gosling, V.L. Schweickart, P.W. Gray, and I.F. Charo. 1996. Molecular cloning and functional characterization of a novel human CC chemokine receptor (CCR5) for RANTES, MIP-1 $\beta$, and MIP-1 $\alpha . J$. Biol. Chem. 271:17161-17166.

31. Ernst, C.A., Y.J. Zhang, P.R. Hancock, B.J. Rutledge, C.L. Corless, and B.J. Rollins. 1994. Biochemical and biologic characterization of murine monocyte chemoattractant protein-1. Identification of two functional domains. J. Immunol. 152:3541-3549.

32. Yoshimura, T., E.A. Robinson, S. Tanaka, E. Appella, J.-I. Kuratsu, and E.J. Leonard. 1989. Purification and amino acid analysis of two human gliomaderived monocyte chemoattractants. J. Exp. Med. 169:1449-1459.

33. Grewal, I.S., B.J. Rutledge, J.A. Fiorillo, L. Gu, R.P. Gladue, R.A. Flavell, and B.J. Rollins. 1997. Transgenic monocyte chemoattractant protein-1 (MCP-1) in pancreatic islets produces monocyte-rich insulitis without diabetes Abrogation by a second transgene expressing systemic MCP-1. J. Immunol. 159:401-408.

34. Gunn, M.D., N.A. Nelken, X. Liao, and L.T. Williams. 1997. Monocyte chemoattractant protein-1 is sufficient for the chemotaxis of monocytes and lymphocytes in transgenic mice but requires an additional stimulus for inflammatory activation. J. Immunol. 158:376-383.

35. Rollins, B.J., T. Yoshimura, E.J. Leonard, and J.S. Pober. 1990. Cytokine-activated human endothelial cells synthesize and secrete a monocyte chemoattractant, MCP-1/JE. Am. J. Pathol. 136:1229-1233.

36. Wang, J.M., A. Sica, G. Peri, S. Walter, I.M. Padura, P. Libby, M. Ceska, I. Lindley, F. Colotta, and A. Mantovani. 1991. Expression of monocyte chemotactic protein and interleukin- 8 by cytokine-activated human vascular smooth muscle cells. Arterioscler. Thromb. 11:1166-1174.

37. Graham, G.J., E.G. Wright, R. Hewick, S.D. Wolpe, N.M. Wilkie, D Donaldson, S. Lorimore, and I.B. Pragnell. 1990. Identification and characterization of an inhibitor of haemopoietic stem cell proliferation. Nature (Lond.). 344:442-444.

38. Paul, W.E., and R.A. Seder. 1994. Lymphocyte responses and cytokines. Cell. 76:241-251.

39. Wong, L.-M., S.J. Myers, C.-L. Tsou, J. Gosling, H. Arai, and I.F. Charo. 1997. Organization and differential expression of the human monocyte chemoattractant protein 1 receptor gene. Evidence for the role of the carboxylterminal tail in receptor trafficking. J. Biol. Chem. 272:1038-1045.

40. Cook, D.N., M.A. Beck, T.M. Coffman, S.L. Kirby, J.F. Sheridan, I.B. Pragnell, and O. Smithies. 1995. Requirement of MIP-1 $\alpha$ for an inflammatory response to viral infection. Science. 269:1583-1585.

41. Karpus, W.J., N.W. Lukacs, K.J. Kennedy, W.S. Smith, S.D. Hurst, and T.A. Barrett. 1997. Differential CC chemokine-induced enhancement of T helper cell cytokine production. J. Immunol. 158:4129-4136.

42. Karpus, W.J., N.W. Lukacs, B.L. McRae, R.M. Strieter, S.L. Kunkel, and S.D. Miller. 1995. An important role for the chemokine macrophage inflammatory protein- $1 \alpha$ in the pathogenesis of the T cell-mediated autoimmune disease, experimental autoimmune encephalomyelitis. J. Immunol. 155:50035010.

43. Karpus, W.J., and N.W. Lukacs. 1996. The role of chemokines in oral tolerance: Abrogation of nonresponsiveness by treatment with anti-monocyte chemotactic protein-1. Ann. NY Acad. Sci. 778:133-144.

44. Kurihara, T., and R. Bravo. 1996. Cloning and functional expression of mCCR2, a murine receptor for the chemokines JE and FIC. J. Biol. Chem. 271: 11603-11607.

45. Loetscher, P., M. Seitz, M. Baggiolini, and B. Moser. 1996. Interleukin-2 regulates $\mathrm{CC}$ chemokine receptor expression and chemotactic responsiveness in T lymphocytes. J. Exp. Med. 184:569-577. 